\title{
Cleanliness as a Part of Mari Identity
}

\author{
Ildikó Lehtinen \\ University of Helsinki
}

\begin{abstract}
The focus of this study is the concept of cleanliness among the Mari, a people speaking a Finno-Ugrian language living in the Volga region of Russia. I personally had a chance to carry out ethnological expeditions in the Mari Republic and in the Mari villages of the Bashkir, Tatar and Udmurtian Republics, and the Kirov and Perm regions from 1981 until recently. In this article, I discuss the concept of hygiene among Mari women and the changes it went through from the Soviet times until today. I explore cleanliness discourse and practice as a traditional moral concept, and as a concept of hygiene adapted by Soviet mass culture. How has the propaganda of health and hygiene influenced the practices of everyday life? What was the connection between the traditional concept and the propaganda of power?
\end{abstract}

Keywords: cleanliness concept, sacred water, body care, gender, changing attitude to cleanliness, everyday life, folk dress.

"Our group of researchers and students arrived in the Mari village of Uncho in June 2002. The head of the cooperative and the head of the village accommodated us at the kindergarten. In the beginning, we had a meeting about the fieldwork, but the first question related to cleanliness. Where and how to wash? It was the main problem for the villagers. In the kindergarten, we had fresh water, but it was cold. The head of the cooperative decided immediately that the villagers have to invite the guests to the bathhouse. After this meeting, we had invitations to wash in different bathhouses."1

The above experience is a proper example of cleanliness as a concept. Hygiene joined the researchers and students from Finland with the Mari villagers. It was problematic for both, especially the Mari homemakers and hosts. Our fieldwork continued the next year, in 2003. We had a new challenge as the kindergarten was under renovation.

${ }^{1}$ LehtinEn Field notes 2002. We had a joint project between Finland and the Mari Republic in Russia. From Finland, the Universities of Helsinki and Turku participated, as well as the Museum of Cultures, from the Mari, the Research Institute of the Mari Republic. The results of the project were published in LEHTINEN 2009. 


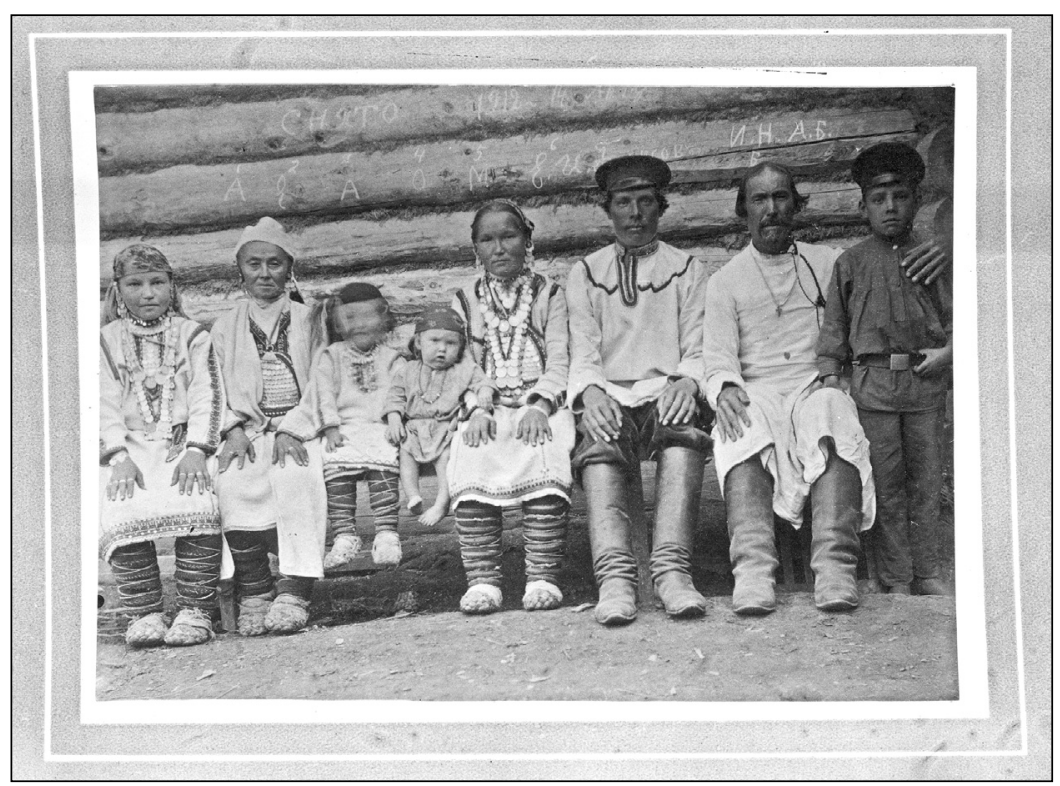

Figure 1. A Mari family. White dress - pure soul. The village of Azial, the Mari Republic, 1910. National Board of Antiquities, Helsinki. (Photo by Timofei Yevseev)

Immediately, the head of the cooperative decided to build a bathhouse for us, and the work began the next morning in the yard of the kindergarten. The notion of hygiene followed me in my expeditions in the Mari villages for 25 years. The villagers offered the researcher the possibility to wash up in the sauna in every part of the Mari speaking region.

Cleanliness is a part of Mari mentality. Nikandr Popov, the Mari ethnologist pointed out that the Mari ideal is a "man who has a pure soul." What is a "pure soul?" It is the purity of thinking, talking and doing, and at the same time it includes the cleanliness of body, health and power (Popov 2013:311). Cleanliness is also emphasized by Mari folk clothing, which consists of a white dress decorated with embroidery.

Nadya L. Peterson studied the cultural connotations of cleanliness in Soviet Russia. She pointed out that cleanliness was and still is a woman's duty - an invisible part of culture: traces of women's daily behavior often become visible only in recorded acts of negation of these norms (PETERSON 1996:182). Sonya, a Mari teacher in the Sosnovka village, stated the same idea in the following form: "In the hands of the woman, it is a ball of thread. She pulls all the threads and takes care of all the activities of everyday life, like the children, the clothing, and the home, the economic situation of the family, the milking and the work." 2

The dichotomy of clean/unclean (ordered/disordered) is directly related to the social organization of space (Douglas 1966:35). The visible manifestations of cleanliness (dress, home, environment) are clear signs of the division between private and public realms characteristic of middle-class society (Vigarello 1988:160). Cleaning

\footnotetext{
${ }^{2}$ LeHTinen Field notes 2009, Bashkortostan.
} 


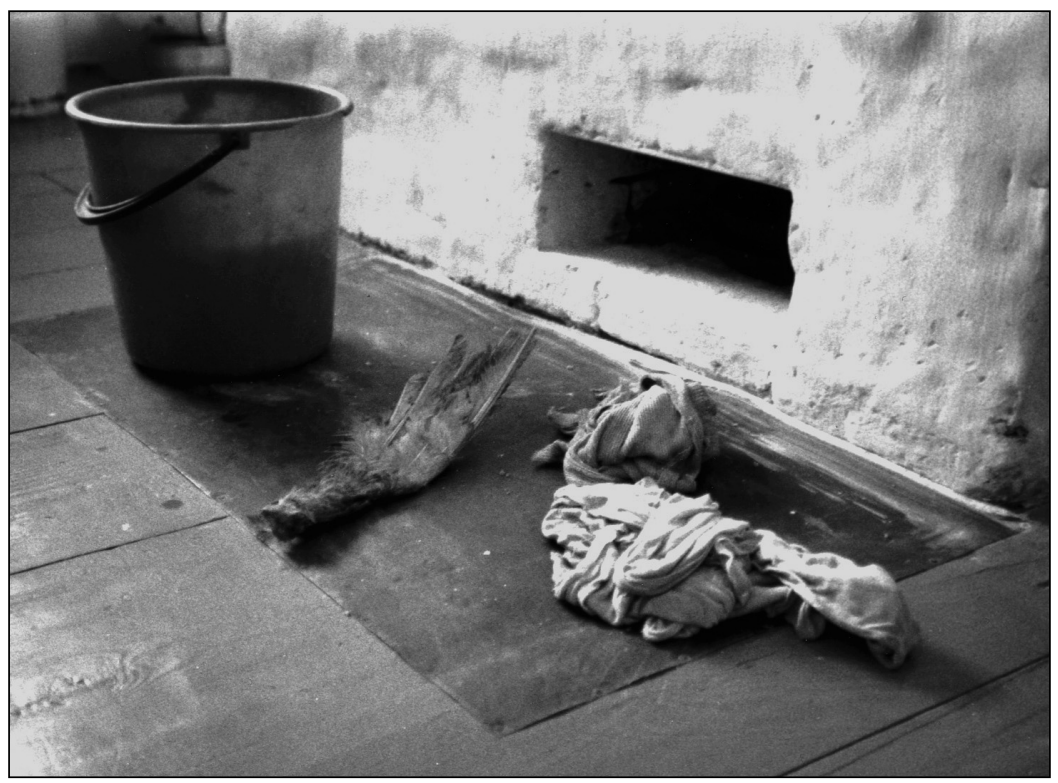

Figure 2. Cleanliness of the home, it was the duty of women. The village of Uncho, the Mari Republic, 2002. National Board of Antiquities, Helsinki. (Photo by Ildikó Lehtinen)

practices also relate to the body and the environment. A clean house is exclusively a woman's practical responsibility. Order in the house equals the absence of dirt, the proper arrangement of objects, and the efficient management of resources. The woman, especially the mother, is in charge of maintaining this order, and its absence leads to an unhappy household (PETERSON 1996:191).

The focus of this study is the concept of cleanliness among the Mari, a people speaking a Finno-Ugrian language living in the Volga region of Russia. ${ }^{3}$ I personally had a chance to carry out ethnological expeditions in the Mari Republic and in the Mari villages of the Bashkir, Tatar and Udmurtian Republics, and the Kirov and Perm regions from 1981 until recently. I studied Mari women's clothing and everyday practices. I interviewed villagers about their everyday routines. Almost without exception, their responses contained a reference to the past and the continuum of everyday life. All questions, observations and conclusions were made in my role as the "Other," an outsider and a researcher of Mari ethnology. I agree with Judy Attfield that the body is constituted within social relations, and that a person can only establish their individual identity through interrelations with others. Class, gender, age and sexuality are all inscribed on the body (ATTFIELD 2000:238). The body is an individual and subjective thing. Through detailed everyday routines and clothing practices, I obtained answers about the relation of women to the body, even though the subject was very delicate and intimate.

\footnotetext{
${ }^{3}$ The Russian census 2002 registered 604800 people of Mari nationality.
} 
In this article, I discuss the concept of hygiene of Mari women and the changes it went through from the Soviet times until today. I explore cleanliness discourse and practice as a traditional moral concept, and as a concept of hygiene adapted by Soviet mass culture. How has the propaganda of health and hygiene influenced the practices of everyday life? What was the connection between the traditional concept and the propaganda of power?

\section{TRADITIONAL MORAL CONCEPT OF CLEANLINESS}

In Tsarist times, Russia was an underdeveloped, agrarian country with an overwhelmingly peasant population. Rates of illiteracy, poverty, disease, and infant mortality remained very high (Hoffmann 2003:17). Nadya L. Peterson, who studied the cleanliness of Russian women, noted that peasants accepted dirt as an unavoidable and sometimes useful part of their environment (PETERSON 1996:188-189). My Mari informers knew that the concept of cleanliness has changed. Until the 1920s, they had chimneyless smoke cottages, the floor was dirty, and people used the same bast shoes inside and outside. Dirt was an inevitable part of life. The informers from the Uncho village noted that cleanliness was different in the past. "On the floor, we have carpets; in the past there was no carpet, and the floor was without paint. I think that it was very dirty." 4

The traditional Mari farmhouse has always consisted of a dwelling plus various outbuildings. The farm was made up of two parts: the yard and the garden. The yard was divided into two parts: the men's yard and the cattle yard. The men's yard was clean and green, and it was the place for the farmhouse, the storehouse and the summer kitchen, the kota. Traditionally, the place of the sauna was far away from the house, in the vicinity of the river, but nowadays saunas are built in the yard near the house (MoLOTOVA - SEPEEv 2005:209, 211).

"The bathhouse is used on Thursday, on Sunday, and also on the eve of Easter, the Semyk feast for ancestors, and all sacrificial rites, but during the wedding and funeral rites, too. If we have a dirty job, we prepare the oven in the evening. First the men wash, after that the women and children. To wash, we use the twig broom. The north side of the young birch is gathered in early June, from the day of Saint Peter until August. In the sauna lives the sauna-spirit. If you throw some rubbish into the oven of the sauna, the spirit becomes very angry." 5

The bathhouse was and still is a place of cleanliness. Both men and women used the bathhouse. Many periods of life were connected with the bathhouse. It was the place where a child came into the world until the 1960s. On the eve of the wedding, the bride cleaned up with her friends in the sauna. The body of a dead person was washed in the bathhouse. It was the symbol of purity and connected with sacred rituals. By Mari beliefs, there was a guardian spirit (mocha kuva/mocha kugyza) in the bathhouse. It helped in practical tasks, but it had a function of being a moral guardian. The role of the spirit was connected with the ancestor, the first owner of the bathhouse (Honko 1993:76). Traditionally, people washed in the bathhouse on Thursday because Friday was the holy day in their ethnic

\footnotetext{
${ }^{4}$ LeHTinen Field notes 2006.

${ }^{5}$ Lehtinen Field notes 1998, Chorai, AA.
} 


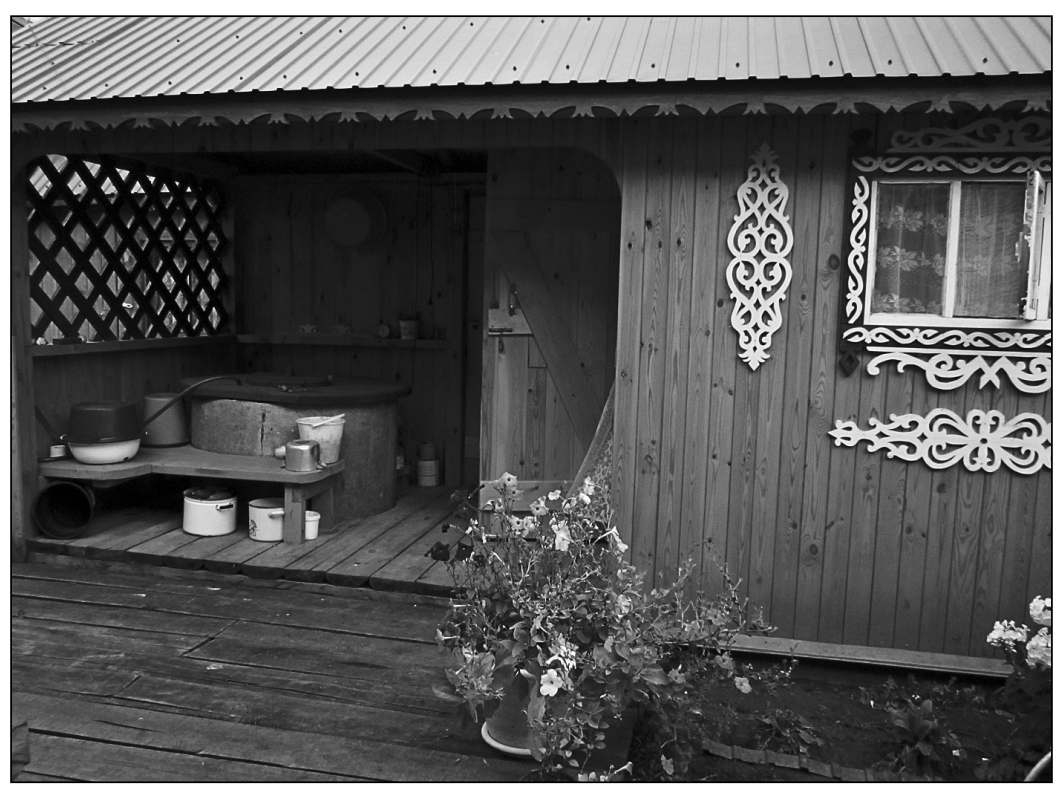

Figure 3. A Mari bathhouse in Nizhni-Novorod district, 2013. (Photo by Ildikó Lehtinen)

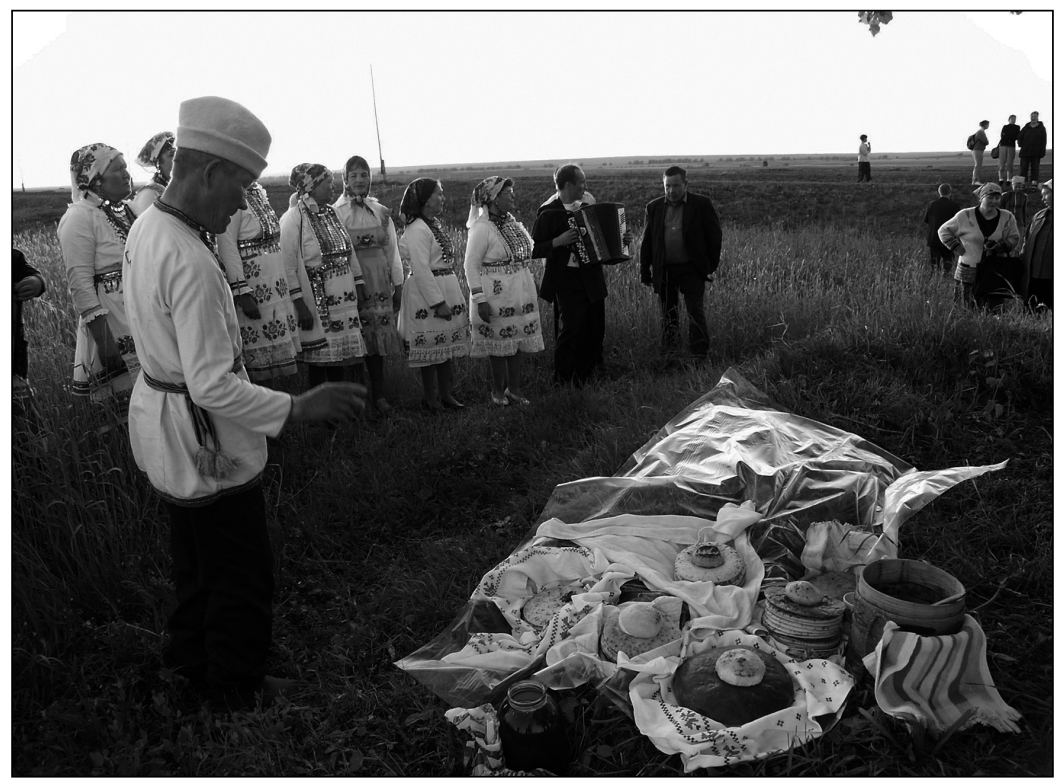

Figure 4. A Semyk-feast, the feast of ancestors in midsummer, on June, 2002. The priest of the ethnic religion sacrifices the food made by women. The village of Uncho, the Mari Republic. National Board of Antiquities, Helsinki. (Photo by Ildikó Lehtinen) 


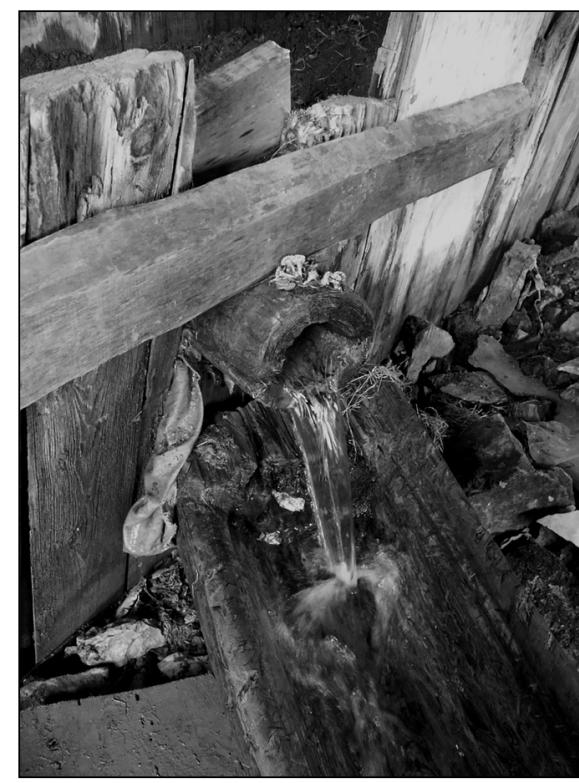

Figure 5. Water, the source of life. Some flowers for the Water-Spirit. The village of Uncho, the Mari Republic, 2009. National Board of Antiquities, Helsinki. (Photo by Ildikó Lehtinen) of purity; all who prayed got clean in the bathhouse and wore a clean dress. Not only those who prayed, but also the participants of the rites had to clean in the sauna and wear a clean dress. The connection with the Gods was successful only through cleanliness.

Mary Douglas writes that contacts regarded as dangerous have symbolic value. She notes, "But as we examine pollution beliefs we find that the kind of contacts which are thought dangerous also carry a symbolic load" (Douglas 1991:3). In the Mari village, cleanliness is a norm that is adhered to. In many places, the activities of everyday life follow a pattern that has been maintained for centuries: water is drawn from the well, and cleaning is done with water and rags.

Contact with the dead is a central idea of Mari worldview. The dead, however, may in this regard represent beliefs associated with pollution. According to this theory, meeting the dead at night requires purification: the living might be at risk if they come into contact with the deceased, and therefore the rite of purification before an encounter with the dead is an important element. The dead, however, may also represent beliefs concerning impurity, and therefore a rite of purification may again be required if they come into contact with a deceased person.

Water is the source of life. Mari villages have always been close to waterways. Alongside cleanness, water is important in everyday life as a part of cooking. It is needed for daily life and the basic need of eating. Another basic need is cleanness, associated with both personal hygiene and keeping one's environment clean. Cleanness is also associated with rites, and it is an indication of one's striving to keep one's own Mari 


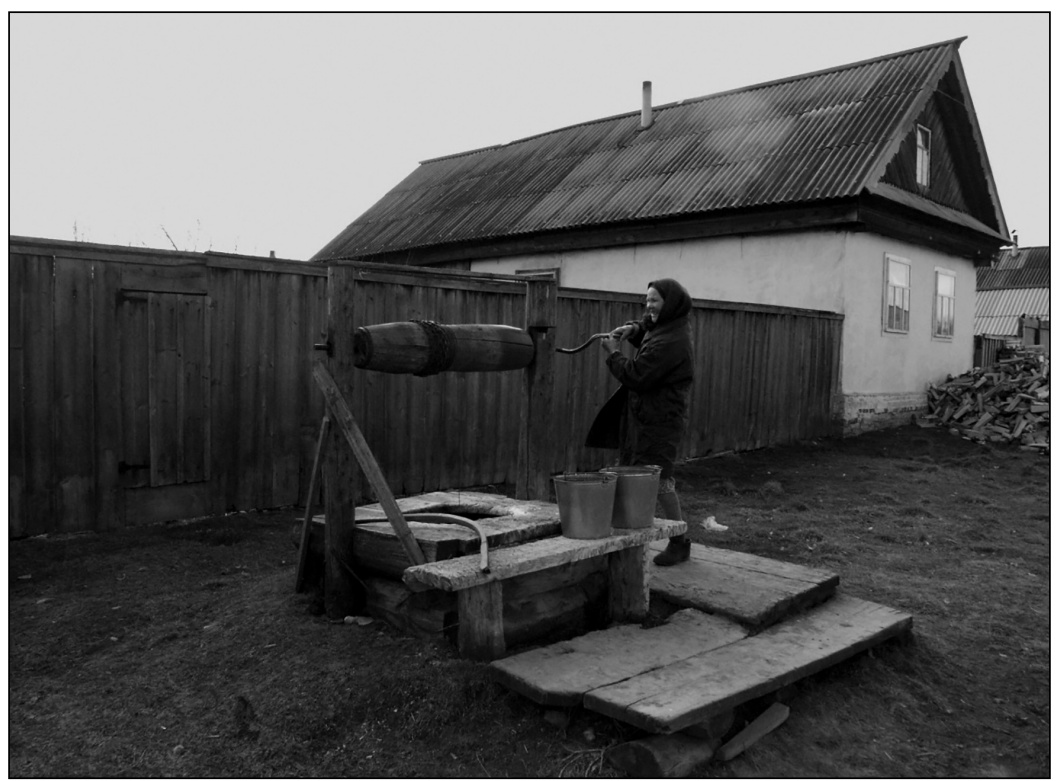

Figure 6. On the well. The village of Uncho, the Mari Republic, 2002. National Board of Antiquities, Helsinki. (Photo by Ildikó Lehtinen)

identity. Bathing in the sauna, clean clothes, the sacred spring and sacred water belong not only to the rites practiced by women but also to the rites of the whole community. In offering feasts conducted by men, women and water represent the "invisible part," which is nonetheless markedly present. Cleanness is in some way comparable to the concept of the sacred, which is similarly invisible and present.

What is cleanliness, according to the informants? It means a clean body, which refers to the bathhouse and to the clean white dresses. Cleanliness means purity of soul, which is the basis of their worldview. The bathhouse and washing in the bathhouse means the need for water, and it is a women's activity. The clean clothing means laundry, which was and still is a women's practice. According to the informers, laundry day was traditionally on Thursday because of their nature religion.

\section{TO TEACH CHILDREN AND THEIR PARENTS TO WASH THEIR HANDS MORE FREQUENTLY - THAT IS ENORMOUS REVOLUTIONARY PROGRESS ${ }^{6}$}

Personal hygiene received special emphasis in Soviet propaganda on cultured behavior. Publications were issued about how to clean various parts of a body, as well as clothes and bedlinens. The Red Army included in its regulations a statement that "each service-man is obligated to follow stringently the rules of personal hygiene, the first and fundamental

\footnotetext{
${ }^{6}$ Nadezhda KrupsKaia 1927 cited by HoffMann 2003:15.
} 


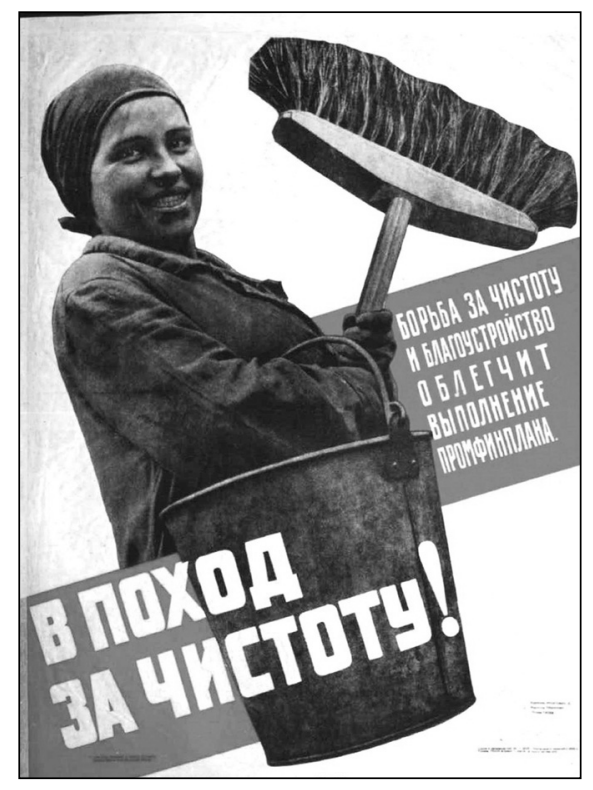

Figure 7. Fight to the cleanliness! Soviet poster of 1930s.

rule of which is cleanliness of the body and clothing." The regulations also required that soldiers wash their hands before eating and brush their teeth both morning and night. Schools also provided an important vehicle by which Soviet authorities could inculcate habits of bodily cleanliness (HoffMANN 2003:19).

Propagandists argued that people needed cleanliness and order at home. The Soviet cultural project aspired to create new people whose values and ways of thinking would be qualitatively different from those who lived under capitalism. The New Soviet Person was to be free of egoism and selfishness, and was to sacrifice personal interests for the sake of the collective. In their attempt to create the New Person, Soviet authorities relied on control of the living environment, education, and inculcation of the practice of working on oneself (Hoffmann 2003:45). The new Soviet citizens were not supposed to spit on the floor, drink to excess, swear, wear dirty clothes, or live in dirty surroundings (PETRONE 2000:13).

Soviet efforts to remake everyday life and create the New Soviet Person, then, met with mixed results. In economic and social terms, Party leaders made considerable progress, albeit at great human cost. In little over a decade, they collectivized agriculture, industrialized the country, and transformed an overwhelmingly rural society into a predominantly urban one. In conjunction with nonparty professionals, Soviet officials also promoted education and hygiene, making enormous strides in the elimination of illiteracy and disease. Soviet authorities sought to reinforce collectivist values though official culture and institutions, such as socialist realist literature, the factory history project, and labor camps. But as with all totalizing projects, the Soviet system failed to refashion all people in all ways. Most citizens, even as they inhabited a world of Soviet norms and values, continued to hold their own beliefs and pursue their own individual interests (HOFFMANN 2003:56-57).

\section{BODY - TRADITIONAL AND SOVIET CONCEPT}

The bathhouse made possible the cleanness of the body. The visible symbol of the clean body was the white clothing. Looking at photos from the 1950s, it is interesting to find that Mari women and men wore the white dress with rich embroidery. The white colour in the Mari language means "clean" and "sacrificial," and it relates cleanliness to purity. "Shining world - it is like a white cloth" (Volgydo mlande - osh vyner), says a Mari proverb (MоLотоva 2013:213). The white dress was preserved in all parts of the Mari region until the 1920s. After that, it was preserved only in the Mari Republic, and in 


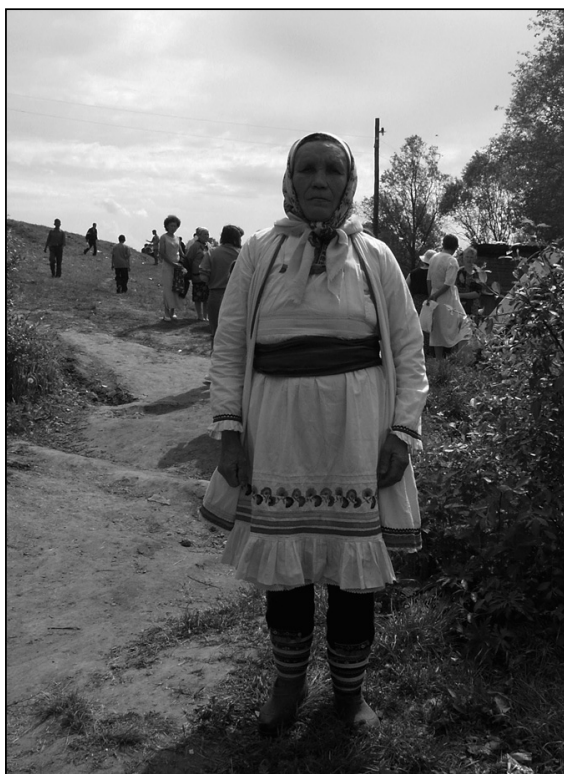

Figure 8. A Mari traditional dress. The village of Uncho, the Mari Republic, 2004. National Board of Antiquities, Helsinki. (Photo by Ildikó Lehtinen) the Kirov region. Between the Mari diasporas in Bashkortostan, Tatarian and Udmurtian Republics and Perm region, the white colour became the symbol of those who prayed and the participants of the sacrificial rites.

People washed in the bathhouse by sex: first the men, and after that the women. Traditionally, the naked body of women was invisible. The concept of a naked body includes religious prescriptions for women. Women's dress was regulated. After the wedding, a Mari woman has to cover her head and legs from the foot to the knee. Mari women felt "naked" without a headdress and socks. "A girl does not walk barefoot. I was dressed in gaiters of black cloth. I wear socks always. I also always have a necklace on my neck. The necklace and the socks I take off only in the bathhouse. It is a sin to walk barefoot" (LEHTINEN 2009:160).

Newly married women covered scrupulously their head and legs in the house of the bridegroom. Both the mother-in-law and the father-in-law kept an eye on the behaviours of the bride. If the father-in-law saw the legs or the hair of the daughter-in-law, the newly married woman had to offer the father-inlaw a drink. The head and the foot were considered erotic stimuli. Maybe these norms protected the young bride from the sexual tensions of the members of the family. ${ }^{7}$

Traditionally Mari clothing consisted of a white dress, an apron, and a coat. As underwear, Mari women used yolash pants, covering the legs to around the knee area. After 1960, women's satin panties appeared in the shops. Recently (1998-2016), in the Mari Republic I observed two different folk costumes, both in white colour:

1. The folk dress of Yoshkar-Ola includes a white shirt and apron. Both items of clothing are decorated with flowered embroidery and lace. The pattern of the long shirt is simply straight. Almost every woman knows how to make a folk costume, and the girls often sew it themselves. Sometimes the grandmother will begin the dress and the granddaughter will finish it. The embroidery is the most important feature; the hem and the front are largely decorated with coloured flowers in satin stitch. The Yoshkar-Ola style dress functions as a national symbol of Mari identity.

2. The ethnic dress, which is made to order for folklore ensembles and individuals. The pattern and the colour of the dresses follows the traditional costume. The basic colour of the dress is white. The embroidery is very complicated, including running and satin stitch, and "Holbein stitch." It takes a long time to make a neo-folk costume, and it is very expensive. The dressmakers also wear these dresses, and I noticed some neo-folk

${ }^{7}$ A paper on the subject of Mari footwear will be published in 2017. 


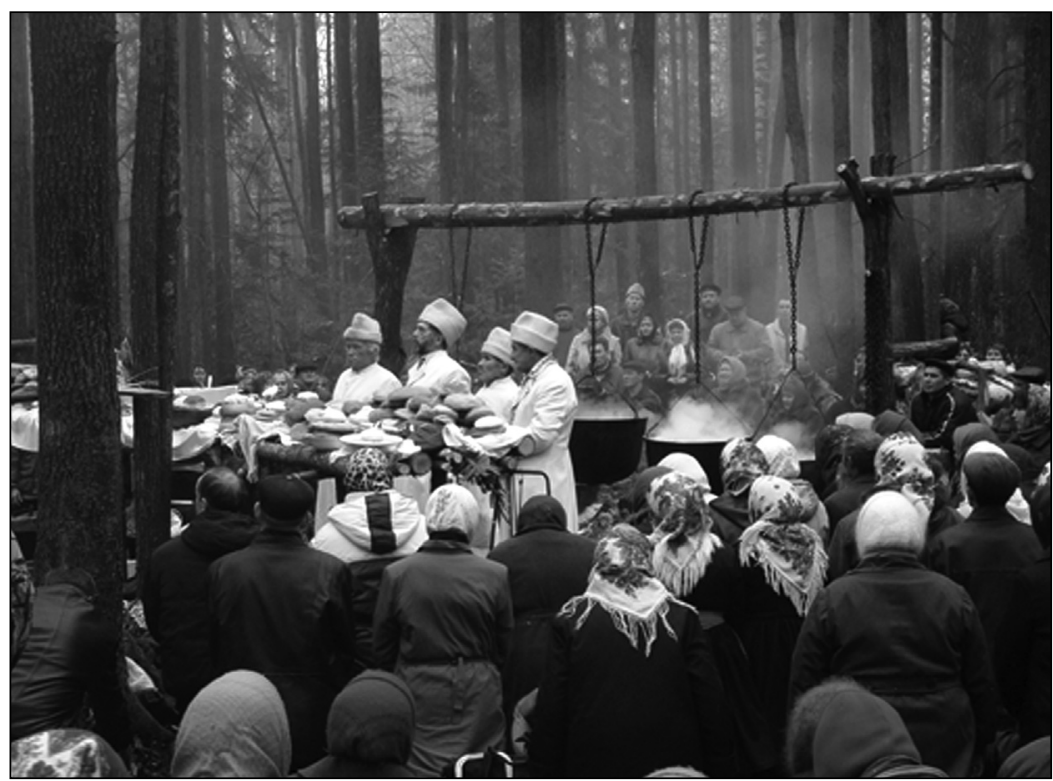

Figure 9. A Mari sacrificial feast in 2007. The priests wore white coats. (Photo by Sergei Tanygin, Ioshkar-Ola)

costumes at the national festival. The neo-folk costume is very popular and "in," and from the girls' point of view it is more interesting than their own embroidered folk costume.

The Mari folk costume is self-evident; everyone knows how a folk costume should look. For the majority of women, the costume is very beautiful and responds to their aesthetic taste and to their concept of purity.

Karen Petrone emphasizes that the body of the individual played a central role in Soviet art and propaganda until 1937. The public appearance of young Russian men and women in shorts and tank tops symbolized the modification of traditional rural attitudes about the body (PETRONE 2000:34). The hygiene of the body was represented in public discourse, in the clubs, in the dormitories and the canteens. Those active in the Communist Party read papers on "How to clean without a bath?" and "How often to change underclothes?" In 1928, they held "Russian week for hygiene," and in 192829, they held meetings about individual cleanliness (LeBINA 2014:97-98). The Soviet woman was a worker and a mother, and her clothing reflected these roles. In the 1950s, Soviet propaganda emphasized the functionality and practicality of underwear, in contrast with Western European fashion, which stressed the sexuality of the woman (Gurova 2008:80).

The new Stalinist elite and Soviet citizens adopted the notion of the woman as a primary organizer of domestic life. Soviet women wore identical simple dresses: a blouse, a large kirtle, a jacket like a man's overcoat, and a scarf, which is still the symbol of the worker (Gurova 2008:81). Proletarka, a Soviet woman, had two lives: the work life, and the everyday life as mother and homemaker. Soviet textile production did not afford Russians the possibility of choosing fashionable clothing. When Stalin told Stakhanovites in November 1935, that "life has become better, comrades, life became 
more joyous, and when you are living joyously, work turns out well," he promised a better life. The life of Soviet women came into focus for the propaganda. In the cities, new shops opened, and the propaganda focused on the hygienic and beautiful hands of women. Women's magazines Rabotnitsa and Krestyanka emphasized that a woman had the possibility of using herself for her beauty. At the same time, the magazines began to show women's underclothes (GUROva 2008:60).

\section{SOVIET BEHAVIOR IN THE COUNTRYSIDE, OR TRANSFORMING TRADITIONAL RURAL PRACTICES}

The Soviet version of modernity certainly had features distinctive to itself. The norms and values promoted by the Soviet government had a particular anti-capitalist, collectivist orientation. The New Soviet Person was to be not only clean, sober and efficient, but also prepared to sacrifice his or her individual interest for the good of the collective, in sharp contrast to the ideal of liberal individualism (HoFfMANn 2003:10).

Collectivization, which involved an enormous amount of coercion directed at the peasant population, was an attempt by the Party leaders to accelerate evolutionary times toward communism. Peasants who were collectivized laborers rather than landowners would shed their petty bourgeois mentality and adopt a socialist consciousness. Those peasants who resisted collectivization were labeled kulaks and deported to labor camps, where they would be reeducated through forced labor (HOFFMANN 2003:49).

Other evidence indicates that a great many Soviet citizens rejected the ideal of the New Person and the values associated with it. People continued to identify their own personal interests apart from and in conflict with the interests of the state. Much of the population also maintained their religious beliefs and continued religious worship, either passively or actively resisting official efforts to promote atheism (HOFFMANN 2003:54).

David L. Hoffmann points that Soviet health propaganda particularly emphasized women's parts in establishing a hygienic and healthy home. Drawing upon traditional gender roles, Soviet officials viewed the domestic sphere as a female realm, and the pamphlets and posters they produced portrayed health in the home as the responsibility of women. Women were expected to clean, prepare healthy meals, care for small children, and provide a restful home environment. Soviet health propaganda, then, not only drew upon but also reinforced traditional gender stereotypes HOFFMANN 2003:23).

What about the Mari example? Mari people always represented a minority in the Soviet Union and in Russia, too. The Russian-language propaganda did not affect the villagers. In 1930, the newspaper Marii Yal presented school girls during a lesson of gymnastics. All girls wore the folk dress. ${ }^{8}$ However, in 1936, the magazine Marii Kommuna showed a new look: the pupils dressed in shorts and T-shirt, a pioneer-scarf around their neck. ${ }^{9}$ It was a propaganda of hygiene related to folk dress. The newspapers U Vii and Mari El turned to Mari women to transform the Mari folk dress into a renewed form. Covering the head and feet was forbidden by the authorities of the health system (LeHTinen 1999:72). The tenacity of this custom was evident well into the 1970s.

\footnotetext{
${ }^{8}$ Marii Yal: republican political newspaper in the Mari language, Yoshkar Ola 1930, 18(7):7.

${ }^{9}$ Marii Kommuna: republican newspaper Mari ASSR, Yoshkar Ola 1936, 4(5):4.
} 


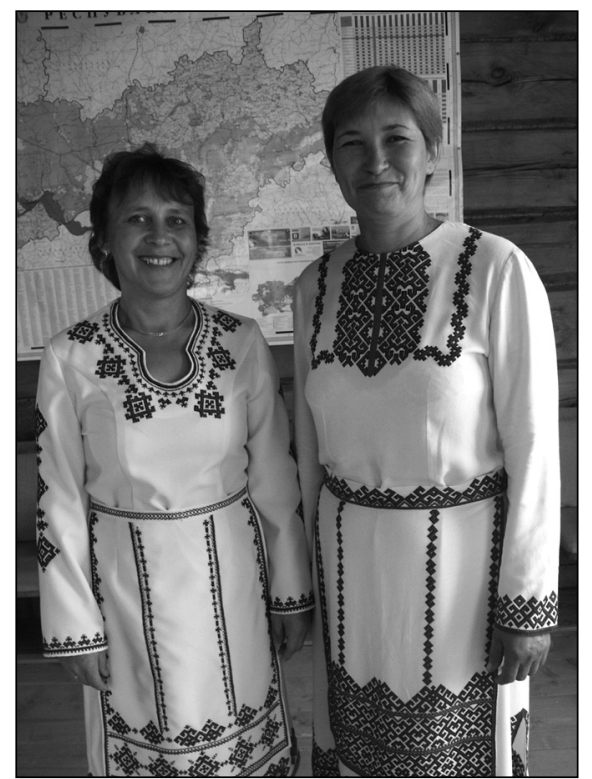

Figure 10. Mari ethnic dress, the reinvented national dress. The village of Uncho, the Mari Republic, 2009. National Board of Antiquities, Helsinki. (Photo by Ildikó Lehtinen)
The new body ideal, the representation of men and women in shorts and tank tops, only arrived in schools after the World War. The traditional concept of the body, the regulations for cleanliness lived on in Mari ethnic religion until the 1960s. Hygiene and cleanliness was also reinforced by the ideology of the Soviet times in veterinary practice.

During the 1950s, the assortment of clothes in stores was limited, and prices were too high for most people. Soviet textile production did not give the Russians or the Mari an opportunity to choose fashionable clothing (VAINSHTEIN 1996:65). During that period, the Soviet woman's wardrobe included a khalat for housework. Later, the inhabitants of the Mari countryside were able to buy new products, satin underclothes, and other clothes. For Mari women the khalat was a dream, and they have only been able to buy a khalat made of flowered cotton since the 1960s. Now the khalat is fairly popular with everyone. Elderly women wear the khalat in the street and at home. Young women and girls use the khalat only in the morning and after the sauna. Today, khalats, T-shirt, jeans and other clothes are used in the countryside and in the villages. The traditional dress is worn on festive days, during the sacrificial rites of the ethnic religion, and during wedding ceremonies. In the post-socialist period, the reinvention of the national dress began, reinforced by the ethnic religion.

\section{REFERENCES CITED}

ATTFIELD, Judy

2000 Wild Things. The Material Culture of Everyday Life. Oxford - New York: Berg.

Douglas, Mary

1966 Purity and Danger. An Analysis of the Concepts of Pollution and Taboo. London and New York: Routledge.

Gurova, Olga

2008 Sovetskoye nizhneye bel'ye: mezhdu ideologiyey $i$ povsednevnosti [Soviet Underwear: between Ideology and Everyday Life]. Moskva: Novoye Literaturnoye Obozreniye.

HoFFMANN, David L.

2003 Stalinist Values. The Cultural Norms of Soviet Modernity, 1917 - 1941. Ithaca - London: Cornell University Press. 
HoNkO, Lauri

1993 Belief and Ritual: The Phenomenological Context. - The Great Bear. In Honko, Lauri - Timonen, Senni - Branch, Michael (eds) A Thematic Anthology of Oral Poetry in the Finno-Ugrian Languages. 63-80. Helsinki: Finnish Literature Society.

LEBINA, Nathalia

2014 Muzhchina $i$ zhenshchina: telo, moda, kul'tura. SSSR - ottepel' [Man and Woman: Body, Fashion and Culture. USSR - Consolidation]. Moskva: Novoye Literaturnoye Obozreniye .

LEHTINEN, Ildikó

1999 Marien mekot. Volgansuomalaisten kansanpukujen muutoksista [Mari's Dresses. Volga-Finnish Folk Costume Changes]. Helsinki: SuomalaisUgrilainen Seura. (Suomalais-Ugrilaisen Seuran Kansatieteellisiä julkaisuja 16).

2009 Alastomuus ja sen merkitys [Nudity and its Significance]. In LEHTINEN, Ildikó (ed) Valkoisen jumalan tyttäret. Marilainen nainen ja modernisaatio. [The Daughters of the White God. Mari Woman and Modernization]. 155-164. Helsinki: Suomalais-Ugrilainen Seura/Finn-Ugor Ushem (SuomalaisUgrilaisen Seuran kansatieteellisiä julkaisuja 19).

Molotova, Tamara Lavrent'yevna

2013 Traditsionnoye tkachestvo [Traditional Weaving]. In KAzImov, A. S. Molotova, T. L. - Nikitina, T. B. - Sharov, V. D. (eds) Mariytsy. Istorikoetnograficheskiye ocherki [Maris. Historical and Ethnographic Essays]. 208213. Yoshkar Ola: MarNIYALI.

Molotova, Tamara Lavrent'yevna - SePeEv, Gennadii

2005 Changes in Mari villages and houses in the 1980s and 1990s. In Lehtinen, Ildikó (ed) Marit, mordvalaiset ja udmurtit. Perinteisen kulttuurin tietosanakirja [Maris, Mordvinians and Udmurts. Encyclopaedia of Traditional Culture]. 208-213. Helsinki: Suomalaisen Kirjallisuuden Seura - Museovirasto.

Popov, N. S.

2013 Narodnyye verovaniya i znaniya [Folk Beliefs and Knowledge]. In KazImov, A. S. - Molotova, T. L. - Nikitina, T. B. - Sharov, V. D. (eds) Mariytsy. Istoriko-etnograficheskiye ocherki [Maris. Historical and Ethnographic Essays]. 287-324. Yoshkar Ola: MarNIYALI.

Peterson, Nadya L.

1996 Dirty Women: Cultural Connotations of Cleanliness in Soviet Russia. In Goscilo, Helena - Holmgren Beth (eds) Russia. Women. Culture. 177-208. Bloomington - Indianapolis: Indiana University Press.

Petrone, Karen

2000 Life Has Become More Joyous, Comrades. Celebrations in the Time of Stalin. Bloomington - Indianapolis: Indiana University Press.

VAINSHTEIN, Olga

1996 Female Fashion, Soviet Style: Bodies of Ideology. In Goscilo, Helena - Holmgren Beth (eds) Russia. Women. Culture. 64-93. Bloomington Indianapolis: Indiana University Press.

VigaRELlo, Georges 
1988 The concept of cleanliness: changing attitudes in France since in Middle Age. Cambridge: Cambridge University Press.

Unpublished sources:

LEHTINEN Ildikó

Field notes in Bashkortostan (1998, 2009) and in Mari Republic (2002). The Archives of the Museum of Cultures / National Museum of Finland. National Board of Antiquities, Helsinki.

Ildikó Lehtinen, Associate Professor of Ethnography, University of Helsinki, former curator at the Museum of Cultures, National Museum of Finland, retired. A specialist of material culture with ample experience in fieldwork, she published widely on the ethnic groups of the Volga region and Siberia. E-mail: ildikolehtinen@gmail.com 